\title{
Studies on the Purification of Chitin Synthase from Coprinus cinereus
}

\author{
By G. W. G. MONTGOMERY, D. J. ADAMS† AND G. W. GOODAY* \\ Department of Microbiology, University of Aberdeen, Aberdeen AB9 IAS, UK
}

(Received 16 June 1983)

\begin{abstract}
Chitin synthase has been characterized from the stipes of Coprinus cinereus by a number of techniques. In the absence of digitonin, on gel filtration columns and during electrophoresis the enzyme showed properties consistent with having molecular weights from $1.5 \times 10^{5}$ to several million, suggesting its reversible aggregation into large multimolecular units. Gel chromatography in buffers containing digitonin gave highly reproducible results, and when followed by anion-exchange chromatography gave preparations with very high activity [e.g. $3.4 \mu \mathrm{mol}$ substrate incorporated $\left.\min ^{-1}(\mathrm{mg} \text { protein })^{-1}\right]$ and apparent molecular weight $8.0 \times 10^{5}$. The best purification (140-fold) was achieved by gel chromatography followed by copper chelate affinity chromatography, giving a nearly pure enzyme preparation of activity $4.7 \mu \mathrm{mol}$ substrate incorporated $\min ^{-1}(\mathrm{mg} \text { protein })^{-1}$, which showed only one band of molecular weight $6.7 \times 10^{4}$ on SDS-polyacrylamide electrophoresis. These purified preparations were free of the nucleoside diphosphatase and protease activities that were present in the early stages of purification.
\end{abstract}

\section{INTRODUCTION}

The membrane-bound enzyme chitin synthase (uridine diphosphate- $N$-acetylglucosamine :chitin $N$-acetylglucosaminyl transferase, EC 2.4.1.16) has been detected in preparations from a wide range of fungi, where it plays a major role in the biosynthesis of the cell wall (Gooday \& Trinci, 1980; Bartnicki-Garcia et al., 1979; Cabib et al., 1979). To date it has not been fully characterized from any source. We present here results of studies aimed at its purification from stipes of the toadstool Coprinus cinereus (Schaeff. ex Fries) S. F. Gray. This source was chosen for four reasons: (a) the initial specific activity is very high (Adams \& Gooday, 1980); (b) there are kinetic data for the activity of this enzyme (de Rousset-Hall \& Gooday, 1975; Gooday, 1977, 1979); (c) the stipe is a specialized tissue, and its elongation involves substantial chitin synthesis (Gooday, 1979); (d) preparations from this source do not require activation by exogenous proteases, in contrast to those from other sources (Cabib et al., 1979).

Characteristics are included of two other types of enzyme activity in the preparations which may play regulatory roles in fungal chitin synthesis: proteases, which may be responsible for endogenous activation of chitin synthase zymogen, and nucleoside diphosphatases which may modulate activity by removing the inhibitory product UDP (de Rousset-Hall \& Gooday, 1975; Gooday, 1979).

\section{METHODS}

Enzyme preparations. Growth of the $C$. cinereus and the preparation of the two digitonin-solubilized enzyme extracts were as described before: a solubilized microsomal preparation (Gooday \& de Rousset-Hall, 1975): and an initially solubilized preparation (Adams \& Gooday, 1980).

Enzyme assays. Assays for chitin synthase were as as described before (Adams \& Gooday, 1980; Gooday \& de Rousset-Hall, 1975), except that incubations of column eluates consisted of an $80 \mu \mathrm{l}$ sample in a total volume of $100 \mu \mathrm{l}$ containing final concentrations of $50 \mathrm{~mm}-\mathrm{Tris} / \mathrm{HCl} \mathrm{pH} 7 \cdot 5,25 \mathrm{~mm}-\mathrm{MgCl}_{2}, 1 \mathrm{~mm}-\mathrm{EDTA}, 25 \mathrm{~mm}-\mathrm{N}$-acetylglucosamine, $1 \mathrm{~mm}$-UDP- $N$-acetylglucosamine ( $10 \mathrm{nCi}$ UDP-[U- $\left.\left.{ }^{1+} \mathrm{C}\right] \mathrm{GlcNAc}\right)$, incubated for between 30 and $60 \mathrm{~min}$ according to activity. Assays for nucleoside diphosphatase, with UDP as substrate, were as described before (de Rousset-Hall \& Gooday, 1975). Assays for proteolytic activities were by measuring rates of increase in absorbance of $405 \mathrm{~nm}$ caused by the release of 4-nitroaniline from solutions of chromogenic model peptide sub-

† Present address: Medical Oncology Unit, Western General Hospital, Edinburgh EH4 2XU, UK.

0022-1287/84/0001-1555\$02.00 (C) 1984 SGM 
strates (Kabi Diagnostica, Stockholm, Sweden), as described by Achstetter et al. (1981). Incubation volumes were $100 \mu \mathrm{l}$ at $37^{\circ} \mathrm{C}$ for $30 \mathrm{~min}$, during which time the rate of release of 4-nitroaniline was linear. Ten peptide sequences were tested: S-2484, S-2337, S-2238, S-2302, S-2160, S-2586, S-2288, S-2444, S-2222 and S-2257. Protein contents were measured according to Bradford (1976).

Electrophoresis. Polyacrylamide gradient gel electrophoresis used prepared gels PAA 2/16 (Pharmacia) in a Uniscil Gradipore system (Universal Scientific Ltd, London, UK) at $4{ }^{\circ} \mathrm{C}$. Upper and lower reservoirs were filled with buffer ( $90 \mathrm{~mm}$-Tris, $80 \mathrm{~mm}$-boric acid, $3 \mathrm{~mm}$-EDTA, pH 8.35), and the system was equilibrated at $125 \mathrm{~V}$ for $15 \mathrm{~min}$, and $70 \mathrm{~V}$ for $20 \mathrm{~min}$. Solubilized microsomal enzyme preparation $(500 \mu \mathrm{l})$ plus bromophenol blue $(0.05 \%$, $\mathrm{w} / \mathrm{v}) /$ glycerol $(1: 1, \mathrm{v} / \mathrm{v})(100 \mu \mathrm{l})$ was layered on the gel and electrophoresed at $125 \mathrm{~V}$ for $15 \mathrm{~h}$. In order to locate enzyme activity a central $4 \mathrm{~mm}$ longitudinal section was removed from the gel and sliced into $1 \mathrm{~mm}$ portions, each of which was incubated in $100 \mu \mathrm{l} 50 \mathrm{~mm}$-Tris/ $\mathrm{HCl} \mathrm{pH} 7 \cdot 5,40 \mathrm{~mm}-\mathrm{MgCl}_{2}, 1 \mathrm{~mm}$-EDTA, $5 \mathrm{~mm}$ - $N$-acetylglucosamine, $4 \mathrm{~mm}$-UDP-GicNAc ( $50 \mathrm{nCi}$ UDP-[U-14 C]GlcNAc), $0.02 \% \mathrm{NaN}_{3}$, at $25^{\circ} \mathrm{C}$ for $24 \mathrm{~h}$. Gel slices were dissolved by immersion for $3 \mathrm{~h}$ at $95^{\circ} \mathrm{C}$ in hydrogen peroxide $(1 \mathrm{ml}, 30 \% \mathrm{w} / \mathrm{v})$, filtered by Millipore GS filters (pore size $0.22 \mu \mathrm{m}$ ) and washed through with $5 \times 1 \mathrm{ml} 1 \%(\mathrm{v} / \mathrm{v})$ Triton X-100 and $15 \mathrm{ml}$ water. Filters were dried and counted for radioactivity (Adams \& Gooday, 1980). The remainder of the gel was stained for protein by immersion in $0.2 \%(\mathrm{w} / \mathrm{v})$ Coomassie Brilliant Blue R250, $10 \%(\mathrm{v} / \mathrm{v})$ acetic acid, $40 \%(\mathrm{v} / \mathrm{v})$ ethanol for $60 \mathrm{~min}$ at $55{ }^{\circ} \mathrm{C}$, and destained in $10 \%(\mathrm{v} / \mathrm{v})$ acetic acid, $15 \%(\mathrm{v} / \mathrm{v})$ ethanol for $30 \mathrm{~min}$ at $55^{\circ} \mathrm{C}$ followed by washing in water and storage in $7 \%(\mathrm{v} / \mathrm{v})$ acetic acid. An identical gel was calibrated with the markers catalase, apoferritin, thyroglobulin and $\alpha_{2}$-macroglobulin.

SDS-polyacrylamide disc gel electrophoresis was as described by Weber \& Osborn (1969), run at $5 \mathrm{~mA}$ per gel for $5 \mathrm{~h}$ and stained as above. SDS-polyacrylamide slab gel electrophoresis was by the method of Laemmli (1970), modified by silver staining as described by Merril et al. (1981).

Column chromatography. Five types of gel matrix were used, all from Pharmacia: Sepharose 4B, Sepharose 6B, Sepharose CL-6B, Sephacryl S-200 Superfine, and Sephacryl S-300 Superfine. Buffers were based on $25 \mathrm{~mm}$ Tris $/ \mathrm{HCl} \mathrm{pH} \mathrm{7.5,} \mathrm{with} \mathrm{additions} \mathrm{where} \mathrm{stated.} \mathrm{All} \mathrm{procedures} \mathrm{were} \mathrm{at} 4{ }^{\circ} \mathrm{C}$. Buffers for gel filtration experiments with Sephacryl columns $(86 \times 1.6 \mathrm{~cm}$ and $56 \times 1.6 \mathrm{~cm})$ contained $0.01 \%(\mathrm{w} / \mathrm{v})$ digitonin (Sigma). The columns were calibrated with a series of molecular weight markers, usually Blue Dextran (Pharmacia), ferritin, catalase, albumin, haemoglobin and RNAase $\mathrm{A}$.

Anion-exchange chromatography. A column $(10 \times 0.8 \mathrm{~cm})$ of DEAE-Sepharose CL-6B was equilibrated with $25 \mathrm{mM}$-Tris $/ \mathrm{HCl} \mathrm{pH} \mathrm{7.5,0.01 \% (w/v)} \mathrm{digitonin.} \mathrm{Active} \mathrm{fractions} \mathrm{from} \mathrm{the} \mathrm{eluate} \mathrm{of} \mathrm{Sephacryl} \mathrm{columns} \mathrm{were}$ applied and eluted under gravity flow with $10 \mathrm{ml}$ Tris/digitonin, followed by $20 \mathrm{ml}$ of a linear gradient of $0-0.4 \mathrm{M}-$ $\mathrm{NaCl}$ in this buffer.

Metal chelate affinity chromatography. The synthesis of the gel matrix was based on the procedure of Porath et al. (1975). Epoxy-activated Sepharose 6B ( $3 \mathrm{~g}$ ) was washed, reswollen and incubated for $24 \mathrm{~h}$ with constant agitation at $65^{\circ} \mathrm{C}$ with $2 \mathrm{~g}$ iminodiacetic acid dissolved in $10 \mathrm{ml} 2 \mathrm{M}$-sodium carbonate. A column $(1.0 \times 10.0 \mathrm{~cm})$ of the product, bis-carboxymethylaminoagarose, was loaded to only two-thirds its length by the passage of a solution of copper sulphate $\left(1 \mathrm{mg} \mathrm{ml}^{-1}\right)$. This was to ensure that no $\mathrm{Cu}^{2+}$ eluted from the column, as this ion is an inhibitor of enzyme activity (Gooday, 1979). The column was equilibrated with $50 \mathrm{~mm}-\mathrm{Tris} / \mathrm{HCl} \mathrm{pH} \mathrm{9.0,0 \cdot 1 \% (w/v)} \mathrm{digitonin.}$ A $2 \mathrm{ml}$ sample of a pool of active fractions from a Sephacryl column, concentrated by ultrafiltration, was applied and eluted with the same buffer, at a flow rate of $9 \mathrm{ml} \mathrm{h}^{-1}$. Fractions of $2 \mathrm{ml}$ were collected and those containing chitin synthase activity were dialysed at $4{ }^{\circ} \mathrm{C}$ against $1 \%(\mathrm{w} / \mathrm{v})$ ammonium bicarbonate and lyophilized.

Affinity chromatography. Agarose-p-aminophenyl- $\beta-\mathrm{D}-N$-acetylglucosamine was supplied by P-L Biochemicals, Milwaukee, USA. Sepharose-hexanolamine-UDP was generously donated by Dr B. Burchell, University of Dundee, UK. Sepharose-adipic acid dihydrazide-UDP was prepared by the method of Lamed et al. (1973). Sepharose-nikkomycin was prepared by incubating $350 \mathrm{mg}$ nikkomycin dissolved in $0.1 \mathrm{M}-\mathrm{NaOH}$ with $5 \mathrm{ml}$ swollen epoxy-activated Sepharose $6 \mathrm{~B}$ for $18 \mathrm{~h}$ at $40^{\circ} \mathrm{C}$ with constant agitation. Any epoxide reactive groups remaining were blocked by soaking the gel in $1 \mathrm{M}$-ethanolamine for $4 \mathrm{~h}$, and excess ligand and contaminants were removed by washing with several volumes of $50 \mathrm{~mm}-\mathrm{Tris} / \mathrm{HCl}, 0.5 \mathrm{M}-\mathrm{NaCl} \mathrm{pH} 8.0$ and $200 \mathrm{~mm}$-acetate buffer. Nikkomycin was a gift from Bayer AG, Leverkusen, FRG.

A column $(0.7 \times 6.0 \mathrm{~cm})$ of nikkomycin-Sepharose was equilibrated with several volumes of saline solution $[0.9 \%(\mathrm{w} / \mathrm{v}) \mathrm{NaCl}, 0.1 \%(\mathrm{w} / \mathrm{v})$ digitonin] and a $5 \mathrm{ml}$ sample of initially solubilized enzyme (dialysed against saline solution) was loaded and eluted with $30 \mathrm{ml}$ of this solution. Affinity elution was then attempted by including $5 \mathrm{ml}$ $2.5 \%(w / v)$ UDP-GlcNAc in the eluant.

The other three affinity gel types were stored at $4{ }^{\circ} \mathrm{C}$ in equilibrating buffer $(100 \mathrm{~mm}-\mathrm{Tris} / \mathrm{HCl} \mathrm{pH} 7 \cdot 5,25 \mathrm{~mm}-$ $\mathrm{MgCl}_{2}, 1 \mathrm{~mm}$-EDTA) containing $0.02 \%(\mathrm{w} / \mathrm{v})$ sodium azide. Chromatography was at $4{ }^{\circ} \mathrm{C}$, on $3 \mathrm{ml}$ columns, with $1 \mathrm{ml}$ initially solubilized enzyme preparation applied and washed on with $15 \mathrm{ml}$ of the Tris buffer. The columns were washed through with $9 \mathrm{ml} 1 \mathrm{mM}$-UDP, $1 \mathrm{~mm}$-UDP-GlcNAc or $1 \mathrm{~mm}$-GlcNAc as appropriate, followed by $9 \mathrm{ml} 10 \mathrm{~mm}$-UDP, $10 \mathrm{~mm}$-UDP-GlcNAc or $10 \mathrm{~mm}$-GlcNAc. The UDP was removed from eluates by ultrafiltration with a Diaflo DM5 membrane (Amicon Corp., Lexington, USA) followed by chromatography on Sephadex G-25 (Pharmacia). 


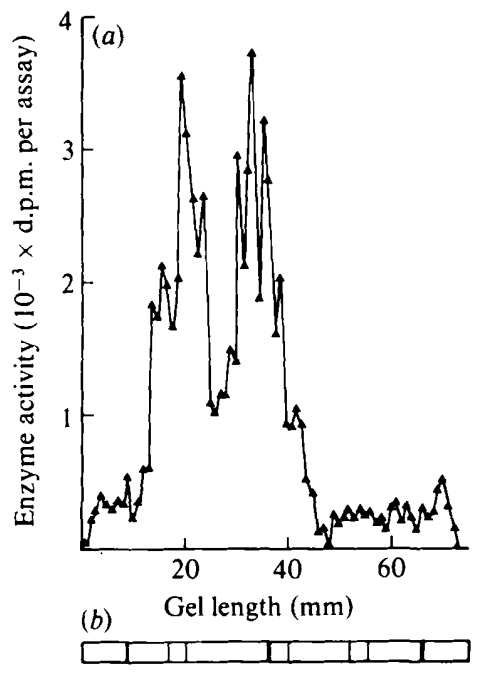

Fig. 1. Electrophoresis of a solubilized microsomal preparation, showing profile of chitin synthase activity $(a)$ and protein staining $(h)$. Gradient electrophoresis gel, from $2 \%$ at $0 \mathrm{~mm}$ (cathode) to $16^{\circ}$ at $73 \mathrm{~mm}$ (anode), run to the exclusion limits of the proteins.

\section{RESULTS}

\section{Purification of chitin synthase}

Two major peaks of activity were obtained from electrophoresis of solubilized microsomal chitin synthase on gradient polyacrylamide gel, corresponding to apparent molecular weights of $7 \times 10^{5}$ and $1.1 \times 10^{6}$ (Fig. 1). Gel permeation chromatography of this enzyme preparation with eluting buffers which did not contain digitonin produced a high recovery of enzyme activity, but poor reproducibility of elution profile. With Sepharose 4B there were often two poorly separated peaks of activity, the first overlapping with the void volume, but sometimes the second peak was missing. This behaviour was not affected by storing or freeze-thawing. The activity usually eluted in the void volume of Sepharose $6 \mathrm{~B}$ columns, indicating a molecular weight $>5 \times 10^{6}$, but became increasingly included in the gel matrix in the presence of increasing concentrations of sodium chloride. Thus in buffer containing $0.2 \mathrm{M}-\mathrm{NaCl}$ the activity eluted as a single peak with a mobility between those of lactose dehydrogenase and catalase, corresponding to an apparent molecular weight of $1.5 \times 10^{5}$.

However, gel chromatography using buffers containing digitonin gave highly reproducible elution profiles. Chitin synthase activity eluted as a single peak from columns of Sephacryl S-200 and Sephacryl S-300 (Fig. 2). The highest activity in the pooled fractions was $1 \cdot 3 \mu$ mol Glc NAc incorporated $\min ^{-1}$ (mg protein) ${ }^{-1}$, representing a 28 -fold purification (Table 1 ). The enzyme activity eluted after the void volume, but with a mobility greater than ferritin, behaving with an apparent molecular weight of approximately $8.0 \times 10^{5}$.

Further purification was achieved by anion-exchange chromatography using DEAESepharose, to give a preparation with an activity of $3.4 \mu \mathrm{mol}$ GlcNAc incorporated $\mathrm{min}^{-1}(\mathrm{mg}$ protein) $)^{-1}$ representing a 73 -fold purification (Fig. 3 : Table 1). SDS-polyacrylamide gel electrophoresis of the most active fractions detected more than one band of staining material, but one band was common to all fractions.

The most successful purification was obtained by chromatography of active fractions from a Sephacryl S-300 Superfine column by metal chelate affinity matrices. Gels with manganese and zinc as the attached cation both gave purifications but the best resolution was obtained with copper when eluted at high $\mathrm{pH}$. The most active fraction from a copper-chelate column was $4.7 \mu \mathrm{mol}$ GlcNAc incorporated $\mathrm{min}^{-1}$ (mg protein) ${ }^{-1}$, representing a 140 -fold purification of 


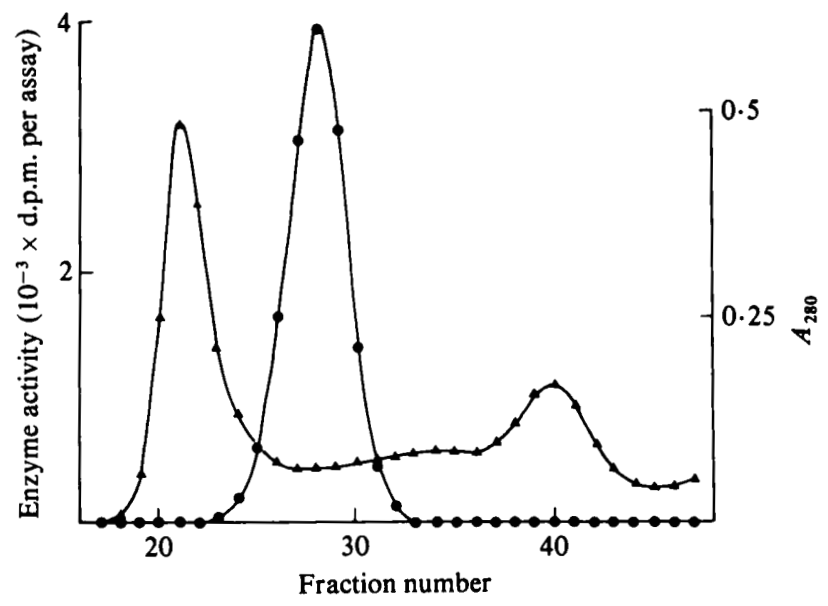

Fig. 2. Typical elution pattern for gel filtration of initially solubilized chitin synthase preparation on Sephacryl S-300 Superfine. Chitin synthase activity; $\boldsymbol{\Delta}, A_{280}$. Column size was $86 \times 1.6 \mathrm{~cm}$, with $2.2 \mathrm{ml}$ sample applied, 75-drop fractions collected. Eluting buffer was $25 \mathrm{mM}$-Tris/ $\mathrm{HCl}, \mathrm{pH} 7.5,25 \mathrm{mM}-$ $\mathrm{MgCl}_{2}, 0 \cdot 5 \mathrm{M}-\mathrm{NaCl}, 1 \mathrm{~mm}-\mathrm{EDTA}, 0 \cdot 01 \%$ digitonin.

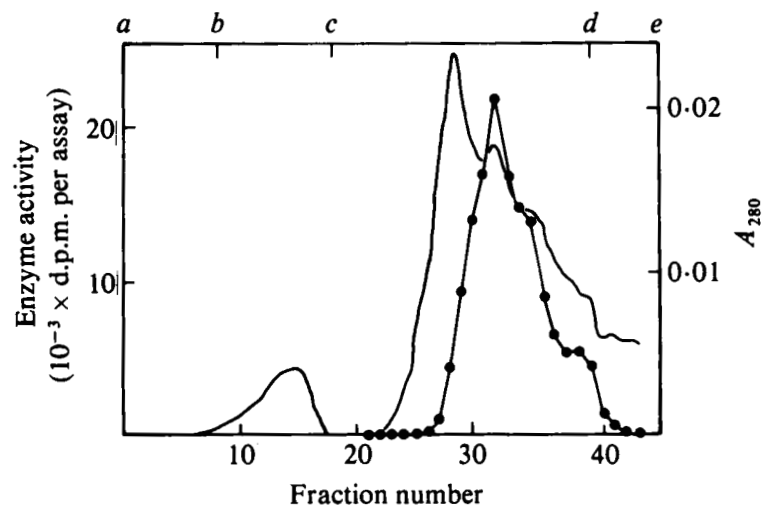

Fig. 3. Anion exchange chromatography of chitin synthase from peak activity from a gel filtration column. Chitin synthase activity;,$-- A_{280}$ (Isco UA5 absorbance monitor). Column was DEAESepharose CL-6B, $10 \times 0.8 \mathrm{~cm} ; a-b$ loading sample in $25 \mathrm{~mm}-\mathrm{Tris} / \mathrm{HCl}, \mathrm{pH} 7.5,0.01 \%$ digitonin, $b-c$ washing with $10 \mathrm{ml}$ buffer, $c-d$ elution with $20 \mathrm{ml}$ linear gradient of $0-0.4 \mathrm{M}-\mathrm{NaCl}$ in buffer, $d-e$ washing with $5 \mathrm{ml}$ buffer; 25 -drop fractions collected.

Table 1. Typical results of purification of chitin synthase from Coprinus cinereus

$\begin{array}{ccccc}\text { Protein } & \begin{array}{c}\text { Protein } \\ \text { applied } \\ \text { collected } \\ (\mu \mathrm{g})\end{array} & \begin{array}{c}\text { Specific activity } \\ \text { [nmol min }\end{array} & \begin{array}{c}\text { Purification } \\ \left.(\text { mg protein })^{-1}\right]\end{array} & \text { (fold) }\end{array}$

(a) Initially solubilized preparation Sephacryl S-300 chromatography DEAE-Sepharose chromatography

(b) Initially solubilized preparation Sephacryl S-300 chromatography Copper-chelate chromatography $(\mu \mathrm{g})$

-

$\begin{array}{rl}46 & - \\ 1300 & 28 \\ 3400 & 73\end{array}$

$33 \cdot 5$

370

4700 


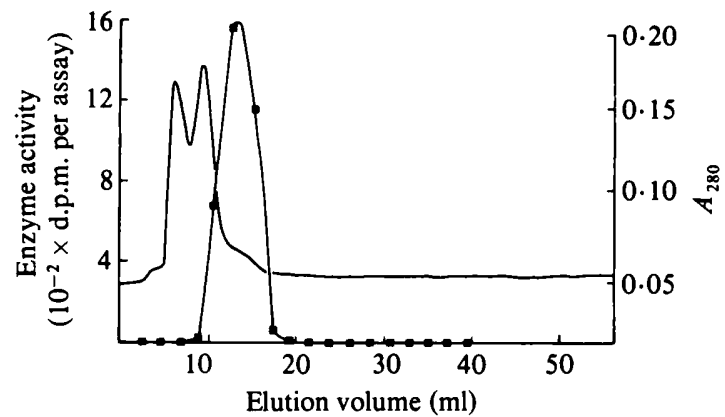

Fig. 4. Copper-chelate chromatography of chitin synthase from peak activity from a gel filtration column. $\square$, Chitin synthase activity;,$- A_{280}$.

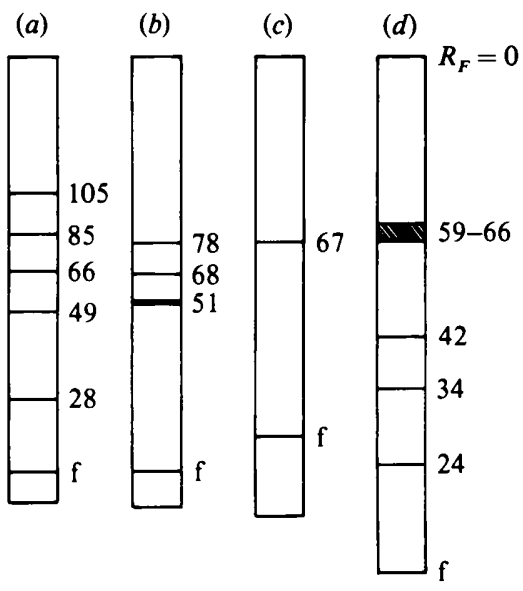

Fig. 5. SDS-polyacrylamide gel electrophoresis of chitin synthase preparations, illustrated by drawings of photographs of representative gels. $(a-c)$ Disc gels, stained with Coomassie Brilliant Blue R, with bromophenol blue marking the front. (a) Initially solubilized enzyme preparations (major components only): (b) peak fraction of chitin synthase activity from a Sephacryl S-300 Superfine column; (c) peak fraction of chitin synthase activity from a copper-chelate column. (d) Slab gel, stained with silver nitrate, of peak fraction of chitin synthase activity from a copper-chelate column. Estimates of molecular weights $\left(\times 10^{-3}\right)$ of each gel are indicated. The position of the front $\left(R_{r}=1\right)$ is indicated by $\cdot{ }^{\prime}$.

the initially solubilized enzyme (Fig. 4; Table 1). The purification was monitored by SDS-polyacrylamide disc gel electrophoresis (Fig. 5), which showed only one band, corresponding to a molecular weight of approximately $6.7 \times 10^{4}$. This band ran in the same position in reducing conditions in the presence of $1 \%(\mathrm{v} / \mathrm{v})$ mercaptoethanol. The product of this combined purification sequence was also analysed by silver-staining an SDS-polyacrylamide slab gel, which also showed the presence of traces of proteins of molecular weights $4.2 \times 10^{4}, 3.4 \times 10^{4}$ and $2.4 \times 10^{4}$ (Fig. 5). However, as this is a very sensitive technique it should be emphasized that these components are present in only nanogram quantities, undetectable by more conventional staining methods, whereas the major $6.7 \times 10^{4}$ molecular weight band represents several micrograms of protein.

The interactions between the enzyme and the four affinity chromatographic supports were as follows: with Sepharose-adipic acid dihydrazide-UDP (linked through - OH groups of ribose), agarose-aminophenyl-GlcNAc (linked through C1) and Sepharose-nikkomycin (epoxide linked via a short hydrophilic spacer arm, probably through phenolic $-\mathrm{OH}$ group), virtually all activity eluted through in the void volume, and no further activity could be washed off; with Sepharose-hexanolamine-UDP (linked through pyrophosphate) over $95 \%$ of the activity appeared in the void volume, and the remaining activity was eluted through as a broad peak by buffer containing UDP but not by buffer containing UDP-GlcNAc. 
Table 2. Protease activities associated with chitin synthase preparations

\begin{tabular}{|c|c|c|}
\hline \multirow[b]{2}{*}{$\begin{array}{l}\text { Peptide } \\
\text { substrate }\end{array}$} & \multicolumn{2}{|c|}{$\begin{array}{l}\text { Protease activity }\left[\Delta A_{405}(30 \mathrm{~min})^{-1}\right. \\
\left.(\text { mg protein })^{-1}\right]\end{array}$} \\
\hline & $\begin{array}{l}\text { Initially solubilized } \\
\text { preparation }\end{array}$ & $\begin{array}{c}\text { Sephacryl S-300 } \\
\text { eluate }\end{array}$ \\
\hline S-2586 & 1.67 & $12 \cdot 1^{*}$ \\
\hline$S-2160$ & 0.93 & 0 \\
\hline S-2337 & 0.81 & 0 \\
\hline S-2484 & 0.33 & 0 \\
\hline S-2222 & $0 \cdot 19$ & 0 \\
\hline S-2288 & $0 \cdot 17$ & 0 \\
\hline S-2302 & $0 \cdot 10$ & 0 \\
\hline S-2444 & $0 \cdot 10$ & 0 \\
\hline S-2238 & 0.07 & 0 \\
\hline S-2251 & 0.07 & 0 \\
\hline
\end{tabular}

* This activity was removed from chitin synthase activity by copper-chelate chromatography. The structure of $\mathrm{S}$-2586 is 3-carbomethoxypropionyl-L-arginyl-L-prolyl-L-tyrosinyl-p-nitroanilide hydrochloride.

Table 3. Nucleoside diphosphatase activity associated with chitin synthase preparations

Fraction

Microsomal preparation

Solubilized microsomal preparation

Sephacryl S-300 preparation

\author{
Specific activity \\ [nmol $\left.\mathrm{min}^{-1}(\mathrm{mg} \text { protein })^{-1}\right]^{*}$ \\ 120 \\ 131 \\ 0
}

* With UDP as substrate; IDP, ADP and GDP were also hydrolysed.

\section{Protease and nucleoside diphosphatase activities}

The initially solubilized preparation contained appreciable activity towards three of the ten synthetic protease substrates (Table 2). The peak with chitin synthase activity resulting from chromatography on Sephacryl S-300 retained activity to one of these, S-2586, which is a model substrate for chymotrypsin. This activity was removed from the chitin synthase activity by copper chelate chromatography (Table 2). As described before (de Rousset-Hall \& Gooday, 1975; Gooday, 1979) nucleoside diphosphatase activity was present in solubilized microsomal preparations, but this was lost from the chitin synthase activity by chromatography on Sephacryl S-300 (Table 3).

\section{DISCUSSION}

The most purified preparation described here gives an apparent molecular weight of $6.7 \times 10^{4}$ in the dissociating conditions on SDS-polyacrylamide gel electrophoresis, in contrast to the molecular weights of several hundred thousand shown by active enzyme preparations eluting from gel filtration columns. This suggests that the active enzyme exists as a multimeric complex. In our preparations this complex is also certainly associated with lipids which are essential for activity (unpublished results).

The estimated molecular weight of the activity recovered by gel filtration is similar to values obtained by Braun \& Calderone (1979) and Duran \& Cabib (1978) for chitin synthase from the yeasts Candida albicans and Saccharomyces cerevisiae respectively, and by Ruiz-Herrera et al. (1980) and Hänseler et al. (1983) for subunits with a sedimentation coefficient of 16 S obtained by treatment of chitosomes of Mucor rouxii and Agaricus bisporus respectively with digitonin.

Some of the increase in specific activity recorded here as purification will be the result of the removal of digitonin, an inhibitor of chitin synthase (Duran \& Cabib, 1978; Ruiz-Herrera et al., 
1980). The 140-fold increase in activity, however, to give an activity of $4.7 \mathrm{nmol}$ GlcNAc incorporated into chitin $\min ^{-1}$ (mg protein $)^{-1}$, does represent the highest level of purity of this enzyme yet recorded, and demonstrates the suitability of the stipe of Coprinus cinereus as a source of the enzyme.

The purification of the chitin synthase from its accompanying nucleoside diphosphatase and protease activities suggests that these are not present in the cell as a multifunctional protein complex. The chymotrypsin-like proteolytic activity which co-purified sevenfold in the chitin synthase fractions requires comment, as serine proteases are usually of low molecular weight (Morihara, 1974), and this had an elution volume on gel filtration columns corresponding to a molecular weight greater than $2.5 \times 10^{5}$. It may be complexing with the membrane lipids in the preparation, and may represent a membrane-bound proteolytic activity in vivo.

We thank Roche Products and the SERC for financial support, Dr K. Söderhäll for the protease substrates, Dr B. Burchell for the UDP-affinity matrix, and Bayer AG for nikkomycin.

\section{REFERENCES}

Achstetter, T., Ehmann, C. \& Wolf, D. H. (1981). Novel proteolytic enzymes in yeast. Archives of Biochemistry and Biophysics 207, 445-454.

ADAMS, D. J. \& GoODAY, G. W. (1980). A rapid chitin synthase preparation for the assay of potential fungicides and insecticides. Biotechnology Letters 2, 7578.

Bartnicki-Garcia, S., Ruiz-Herrera, J. \& Bracker, C. E. (1979). Chitosomes and chitin synthesis. In Fungal Walls and Hyphal Growth, pp. 149-168. Edited by J. H. Burnett \& A. P. J. Trinci. Cambridge: Cambridge University Press.

BRADFORD, M. M. (1976). A rapid and sensitive method for the quantitation of microgram quantities of protein utilizing the principle of protein-dye binding. Analytical Biochemistry 72, 248-254.

Braun, P. C. \& Calderone, R. A. (1979). Regulation and solubilization of Candida albicans chitin synthetase. Journal of Bacteriology 140, 666-670.

Cabib, E., Duran, A. \& Bowers, B. (1979). Localized action of chitin synthase in the initiation of yeast septum formation. In Fungal Walls and Hyphal Growth, pp. 189-201. Edited by J. H. Burnett \& A. P. J. Trinci. Cambridge: Cambridge University Press.

Duran, A. \& Cabib, E. (1978). Solubilization and partial purification of yeast chitin synthetase. Journal of Biological Chemistry 253, 4419-4425.

GoODAY, G. W. (1977). Biosynthesis of the fungal wall - mechanisms and implications. Journal of General Microbiology 99, 1-11.

GOODAY, G. W. (1979). Chitin synthesis and differentiation in Coprinus cinereus. In Fungal Walls and Hyphal Growth, pp. 203-223. Edited by J. H. Burnett \& A. P. J. Trinci. Cambridge: Cambridge University Press.

Gooday, G. W. \& DE Rousset-Hall, A. (1975). Properties of chitin synthetase from Coprinus ciner- eus. Journal of General Microbiology 89, 137145.

Gooday, G. W. \& Trincl, A. P. J. (1980). Wall structure and biosynthesis in fungi. Symposia of the Society of General Microbiology 30, 207-251.

HÄNSEleR, E., NyHLÉN, L. E. \& RASt, D. M. (1983). Dissociation and reconstitution of chitosomes. Biochimica et biophysica acta 745, 121-133.

LAEMMLI, U. K. (1970). Cleavage of structural proteins during the assembly of the head of bacteriophage T4. Nature, London 227, 680-685.

LAMED, R., LEVIN, Y. \& WiLCHEK, M. (1973). Covalent coupling of nucleotides to agarose for affinity chromatography. Biochimica et biophysica acta 304 , 231-235.

Merril, C. R., Goldman, D., Sedman, S. A. \& Ebert, M. R. (1981). Ultrasensitive stain for proteins in polyacrylamide gels shows regional variation in cerebrospinal fluid proteins. Science 211, 1437-1438.

Morihara, K. (1974). Comparative specificity of microbial proteinases. Advances in Enzymology 41. 179-243.

Porath, J., Carlsson, J., Olsson, I. \& Belfrage, G. (1975). Metal chelate affinity chromatography, a new approach to protein fractionation. Nature, London 258, 598-599.

De Rousset-Hall, A. \& Gooday, G. W. (1975). A kinetic study of a solubilized chitin synthetase preparation from Coprinus cinereus. Journal of General Microbiology 89, 146-154.

Ruiz-HerRera, J., BARTNICKI-Garcia, S. \& BraCKer, C. E. (1980). Dissociation of chitosomes by digitonin into $16 \mathrm{~S}$ subunits with chitin synthetase activity. Biochimica et biophysica acta 629, 201-216.

WEBER, K. \& OSBORN, M. (1969). The reliability of molecular weight determinations by dodecyl sulphate-polyacrylamide gel electrophoresis. Journal of Biological Chemistry 244, 4406-4412. 